\title{
Human Ecology and Food Systems: Insights from the Philippines
}

\author{
Federico Davila' \\ Institute for Sustainable Futures, University of Technology Sydney, \\ NSW, Australia
}

\section{Abstract}

Feeding the world sustainably requires balancing social, economic, and environmental concerns. The food systems concept guides the study of social and environmental processes that influence food and nutrition security. Human ecology conceptually offers insights into the social components of a system and its interaction with environmental change. This paper demonstrates how human ecology helps identify the dominant discourses that influence dominant social drivers in food systems. This is done through documenting the historical legacies of agricultural commodity production systems in the Philippines since Spanish colonization, and the human and ecological implications of this history. The analysis shows the presence of a maladaptive system influenced by market-oriented food security as a dominant discourse. Alternative discourses focused on sovereignty and participation exist in the Philippines, however these are often marginalised from dominant policy and research programs. The paper discusses how weak feedback processes provide possible intervention points in policy or farmer-led activities to explore alternative pathways to food and nutrition security. The paper concludes with highlighting how human ecology offers useful framework for advancing food systems analysis into social, political, and policy dimensions of food activities. Such analysis can help develop new research and policies that require managing the competing discourses of how to achieve sustainable food and nutrition security.

Keywords: food security, food sovereignty, human ecology, Philippines

\section{Introduction}

Feeding the world sustainably is a major global challenge that requires balance across sociopolitical tensions, nutritional and aspirational needs of a growing population, ecosystem stability, and climate change (Rockström et al., 2016). Despite being a heavily debated concept, food and nutrition security is commonly understood as

1 Corresponding author: federico.davila@uts.edu.au. 
a normative global policy objective that is achieved when all people have access to sufficient safe and nutritious food to meet their dietary needs and preferences for an active and healthy lifestyle (Food and Agriculture Organization [FAO], 2017). Yet, despite an apparent abundance of food in world markets, 815 million people remain hungry, 1 billion lack micronutrients, and 2 billion are overweight (FAO, 2017). Traditional approaches to solving food and nutrition security challenges have focused on maximizing production of specific commodities, often neglecting broader human and environmental issues (Ingram, 2011). To address this neglect, systems-based approaches have emerged as a way of identifying drivers and feedbacks that influence food activities (Ericksen, 2008; Ingram, 2017; International Panel of Experts on Sustainable Food Systems [IPES Food], 2015; Marin et al., 2016). The concept of food systems acts as a normative way of contextualizing food research and policies (Ericksen, 2008; Ingram, 2011; Ingram et al., 2010).

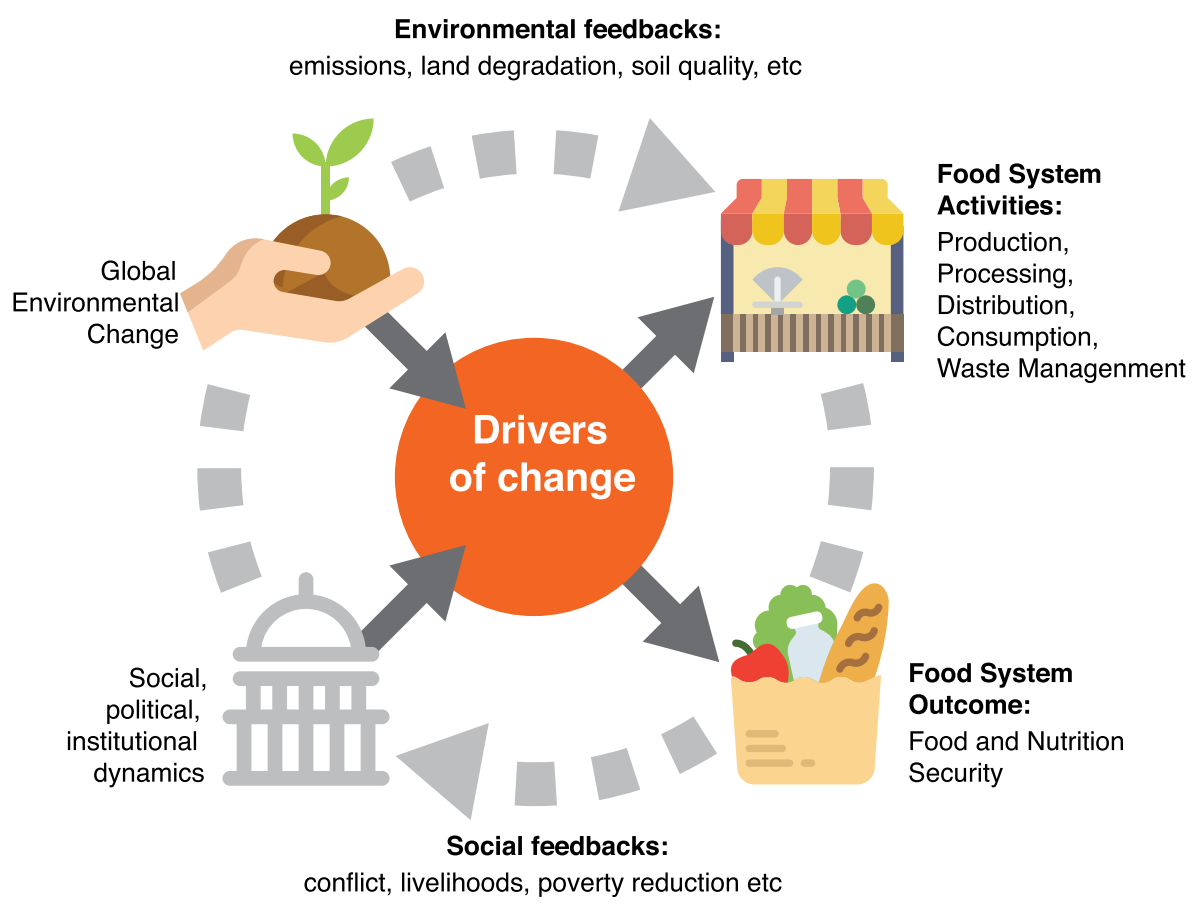

Figure 1. Food system drivers, activities and outcomes

Source: Based on Ericksen (2008), synthesized by the author.

A food system (Figure 1) is made up of interactions between biophysical and human systems that influence food activities ranging from production to consumption (Ericksen, 2008). Food systems operate across spatial and temporal scales, and are managed to deliver food and nutrition security while attempting to reduce negative environmental and social impacts (Ericksen, 2008; Ingram, 2011; Ingram et al., 2010; IPES Food, 2015). The food systems concept is a mental construct that allows 
researchers and practitioners to conduct analysis on specific individual and collective activities, and their interactions with environmental changes (Ingram, 2017). The food systems concept is not new; McMichael (1994) and Sobal et al. (1998) debated initial systems-based approaches to analyzing global food challenges in the 1990s. The lack of coherent focus on feedback between environmental change and food insecurity led to a redeveloped food systems concept (Ericksen, 2008; Ingram, 2011), which enables interdisciplinary study design and conduct. Recent social sciences studies have examined the social drivers of change in food systems, and there has been growing interest in food systems governance and institutional studies (Hospes \& Brons, 2016; Candel, 2014; Termeer et al., 2018), how the political economy affects equity issues associated with trade systems (Clapp, 2015, 2017), and how environmental and political issues interact to influence food system feedbacks (Galt, 2013).

The ongoing use of food systems as a platform to study human ecological interactions presents an opportunity to explore how human ecology frameworks can contribute to food systems scholarship. Human ecology offers a coherent systemsbased approach for capturing the underlying discourses that influence food activities across scales (Davila \& Dyball, 2018; Dyball \& Newell, 2015), notably, the ongoing institutional and political interactions between global market-driven food security and community-oriented food sovereignty (Leventon \& Laudan, 2017; Candel, 2014). Discourses are the underlying ideas that stimulate human activity and collective action (Dryzek, 1997). Studies into food discourses are extensive, yet there remains a need to study how competing discourses exist in particular contexts, their origins, and the implications for transdisciplinary research into future food systems (Marin et al., 2016). Human ecology is defined here as an analytical framework (see Table 1) that captures the underlying discourses and associated feedbacks of these on institutions, human well-being, and ecosystems. Four major variablesstate of discourses, institutions, human well-being, and institutions - align with major elements of the food systems concept, showing complementarity between the frameworks (Table 2). The novel addition of human ecology introduces a focus on food discourses in a specific context and its influence on the system's behavior (Davila \& Dyball, 2018).

The aim of this paper is to show how human ecology helps to identify the dominant discourses that influence the social drivers in food systems. This is demonstrated through documenting the historical legacies of agricultural commodity production systems in the Philippines since Spanish colonization, as well as the human ecological consequences of these. The Philippines comprise 7,000 islands occupying $300,000 \mathrm{~km}^{2}$. Approximately 100 million people inhabit the country; half that number remain in rural areas working largely in agriculture. More than one-quarter (25.8\%) remain below of poverty line (Philippine Statistic Authority, 2014a). The total agricultural land-approximately $125,000 \mathrm{~km}^{2}$ (FAO, 2011)—contributes $12-20 \%$ of gross domestic product (GDP) (Cororaton \& Corong, 2009). Over 
half the population depend either directly or indirectly on income generated through agricultural production (United Nations Development Programme [UNDP], 2013). An ongoing focus on staple commodities such as rice, sugar, and maize has narrowed the focus on rural development opportunities and failed to create diversity of livelihood opportunities (UNDP, 2013).

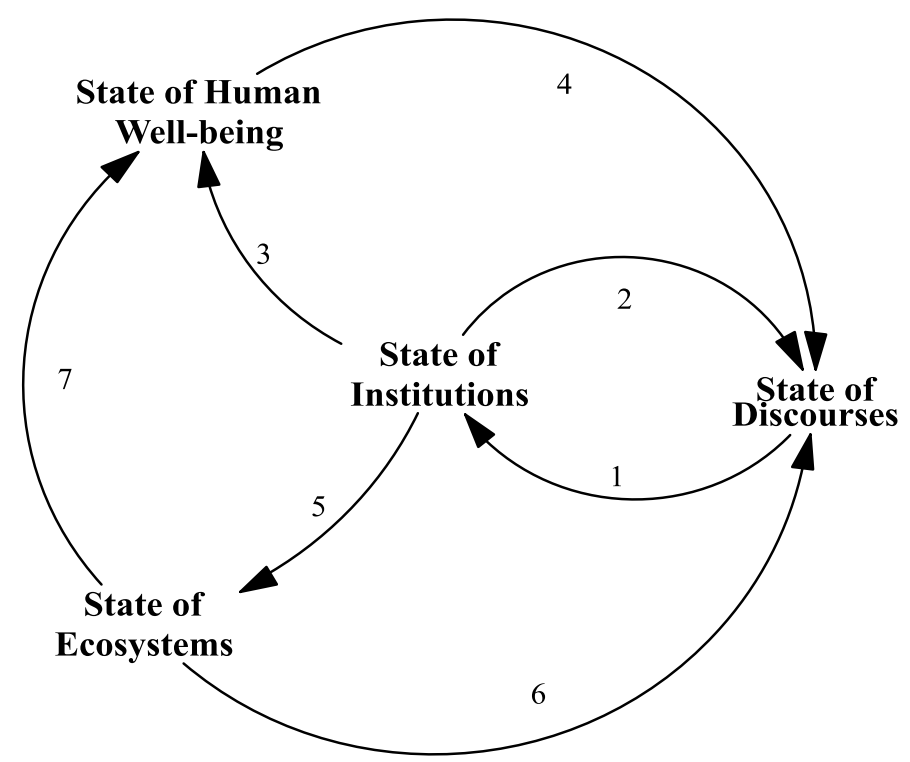

Figure 2. The human ecology framework

Source: Based on Dyball and Newell (2015).

\section{Table 1. The human ecology framework}

\begin{tabular}{|l|l|}
\hline Link number & Process represented by the link \\
\hline 1 & $\begin{array}{l}\text { The influence that a dominant discourse has on generating formal and informal } \\
\text { decisions among individuals or institutions. This includes planning and goal setting } \\
\text { resulting in the design and implementation of policies to promote the dominant } \\
\text { discourses in society. }\end{array}$ \\
\hline 2 & $\begin{array}{l}\text { As formal and informal institutions learn from experiences, they will either reinforce or } \\
\text { change the dominant discourse. Dominant discourses may change or resist change, } \\
\text { as other institutions might reinforce it. If they were changed, they would influence the } \\
\text { formation of new institutions to reflect the new discourse. }\end{array}$ \\
\hline 3 & $\begin{array}{l}\text { This link shows the implications of institutional decisions on an individual } \\
\text { Or a community's physical and psychological well-being. }\end{array}$ \\
\hline 4 & $\begin{array}{l}\text { As communities and individuals change based on institutional activities, dominant } \\
\text { discourses may shift, eventually creating new institutional interventions. As with } \\
\text { L2, these observations may challenge or reinforce core values, depending on } \\
\text { circumstances. }\end{array}$ \\
\hline 5 & $\begin{array}{l}\text { This includes collective activities promoted or enabled by dominant social institutions } \\
\text { that directly affect the environment. }\end{array}$ \\
\hline
\end{tabular}




\begin{tabular}{|l|l|}
\hline Link number & Process represented by the link \\
\hline 6 & $\begin{array}{l}\text { As ecosystems change based on formal and informal institutional activities, } \\
\text { new discourses may emerge or dominant discourses may be perpetuated. }\end{array}$ \\
\hline 7 & $\begin{array}{l}\text { Ecosystems are affected by policies and human behavior and, as ecosystems } \\
\text { change, they directly affect human health and well-being. }\end{array}$ \\
\hline
\end{tabular}

Table 2. Links between human ecology and food systems

\begin{tabular}{|c|c|c|c|}
\hline $\begin{array}{l}\text { Human ecology } \\
\text { framework } \\
\text { variable }\end{array}$ & Overview & $\begin{array}{l}\text { Relevance to food systems } \\
\text { concept }\end{array}$ & $\begin{array}{l}\text { Further } \\
\text { reading }\end{array}$ \\
\hline $\begin{array}{l}\text { State of } \\
\text { discourses }\end{array}$ & $\begin{array}{l}\text { Refers to the collectively held } \\
\text { ideas that frame the nature of } \\
\text { a problem. Discourses may } \\
\text { not be shared equally, but the } \\
\text { framework draws attention to } \\
\text { those that are dominant and } \\
\text { most responsible for a system's } \\
\text { behavior. At the same time, the } \\
\text { framework can reveal alternate } \\
\text { discourses that are currently } \\
\text { marginalized or oppressed but } \\
\text { that, if empowered, could set } \\
\text { different goals for the system. }\end{array}$ & $\begin{array}{l}\text { The food systems concept } \\
\text { identifies social activities } \\
\text { as key drivers of change } \\
\text { in the system. The study } \\
\text { of discourses sheds light } \\
\text { into how individuals and } \\
\text { institutions have come to } \\
\text { frame food problems and, } \\
\text { hence, how they interact } \\
\text { with the system. }\end{array}$ & \begin{tabular}{|l} 
Hospes \& \\
Brons (2016) \\
Jarosz (2014) \\
Rivera-Ferre \\
(2012)
\end{tabular} \\
\hline $\begin{array}{l}\text { State of } \\
\text { institutions }\end{array}$ & $\begin{array}{l}\text { Describes the social institutions } \\
\text { that the community has } \\
\text { established to govern their } \\
\text { collective behavior. These are } \\
\text { the formal and informal rules } \\
\text { and institutions that facilitate } \\
\text { a community's actions. Formal } \\
\text { institutional rules manifest } \\
\text { as policy instruments, such } \\
\text { as taxes, regulations, and } \\
\text { education programs. Informal } \\
\text { institutional rules are those } \\
\text { tacit regulations that influence } \\
\text { what a community judges to be } \\
\text { appropriate "normal" conduct. }\end{array}$ & $\begin{array}{l}\text { Institutions, formal and } \\
\text { informal, are responsible } \\
\text { for managing landscapes } \\
\text { and food production. This } \\
\text { includes smallholder farmers' } \\
\text { organizations, multiple } \\
\text { public agencies, and private } \\
\text { corporations, among others. }\end{array}$ & \begin{tabular}{|l} 
Candel (2014) \\
Chaifetz \& \\
Jagger (2014) \\
Clapp (2017)
\end{tabular} \\
\hline $\begin{array}{l}\text { State of } \\
\text { ecosystems }\end{array}$ & $\begin{array}{l}\text { Includes both the } \\
\text { natural environment and } \\
\text { anthropogenically constructed } \\
\text { artefacts, such as agricultural } \\
\text { landscapes, buildings, roads, } \\
\text { and vehicles. }\end{array}$ & $\begin{array}{l}\text { Infrastructure provides an } \\
\text { avenue for different actors to } \\
\text { produce, distribute, consume, } \\
\text { and dispose of food products. } \\
\text { Natural ecosystems provide } \\
\text { crucial services to agriculture, } \\
\text { yet food activities continue to } \\
\text { pressure these ecosystems } \\
\text { through intensive practices. }\end{array}$ & $\begin{array}{l}\text { Ingram et al. } \\
\text { (2010) } \\
\text { Mclntyre et al. } \\
\text { (2009) } \\
\text { Vermeulen } \\
\text { et al. (2012) }\end{array}$ \\
\hline
\end{tabular}




\begin{tabular}{|c|c|c|c|}
\hline $\begin{array}{l}\text { Human ecology } \\
\text { framework } \\
\text { variable }\end{array}$ & Overview & $\begin{array}{l}\text { Relevance to food systems } \\
\text { concept }\end{array}$ & $\begin{array}{l}\text { Further } \\
\text { reading }\end{array}$ \\
\hline $\begin{array}{l}\text { State of human } \\
\text { well-being }\end{array}$ & $\begin{array}{l}\text { This captures the physical } \\
\text { and psychosocial aspects of } \\
\text { what it means to live well. This } \\
\text { includes indicators of good } \\
\text { health, such as adequate } \\
\text { nutrition. The arrows that } \\
\text { link the four variables are } \\
\text { feedback processes or activities } \\
\text { that influence, positively or } \\
\text { negatively, the metavariable. }\end{array}$ & $\begin{array}{l}\text { Food and nutrition security is } \\
\text { a heavily debated concept, } \\
\text { yet there is general agreement } \\
\text { that this ought to be the } \\
\text { goal of a food system. This } \\
\text { aspect of human well-being } \\
\text { can have long-term human } \\
\text { development impacts through } \\
\text { healthier communities. }\end{array}$ & $\begin{array}{l}\text { Sobal et al. } \\
\text { (1998) } \\
\text { Zamora et al. } \\
\text { (2013) } \\
\text { Fanzo (2014) }\end{array}$ \\
\hline
\end{tabular}

The dominant Philippines food system is defined here as one that focuses on production of commodities for international markets, supported by high productivityoriented policies and technological development (Davidson, 2016; Timmer, 2014, 2015; UNDP, 2013). This system was selected because the country's dominant land use continues to be oriented toward key cash crops, which often encroach on traditional and indigenous local food systems (Borras, 2007; Cororaton \& Corong, 2009; Timmer, 2015). This paper builds on previous human ecology work conducted on Philippines food systems (Carpenter, 2003, 2010; Rambo \& Sajise, 1984) and contributes to growing regional efforts to expand from agroeconomic and technical approaches to food studies (Depositario \& Saguiguit, 2014). The paper contributes to growing interest in expanding from traditional disciplinary-based approaches of agricultural development toward more integrative systems-based ones that capture competing stakeholder understandings of food and nutrition security, both in the Philippines and globally (Depositario \& Saguiguit, 2014; Jarosz, 2014; Leventon \& Laudan, 2017; Marin et al., 2016; Southeast Asian Regional Center for Graduate Study and Research in Agriculture [SEARCA], 2014).

The next four sections populate the human ecology framework with interdisciplinary literature from the Philippines. The "state of human well-being" variable presents issues of nutritional well-being for human development and income inequality in rural agricultural landscapes. The "state of ecosystems" variable shows how dominant commodity production has led to deforestation and affected the country's unique biodiversity; the growing threat that climate change presents to the food system is also discussed. The "state of institutions" section narrates how different policy and land use practices were established by Spanish colonizers and built on by the United States (US) before the country's independence. The institution and trade systems that were established paved the way for the dominant practices of distributing and managing land. The "state of discourses" variable presents the tensions between productivity-oriented production and farmer-led learning activities, demonstrating the tensions between the dominant discourse of production and the marginalized discourses of alternative food systems. After synthesizing this material into the 
human ecology framework, I discuss the positive, negative, and weak feedback processes in the system, and consider several possible points of intervention. The paper concludes by identifying the contributions that human ecology makes toward systemically analyzing social drivers in food systems.

\section{State of human nutrition and economic well-being}

The national Philippine food system is not delivering adequate food and nutritional security outcomes to the Philippines population (Davidson, 2016; Philippine Statistic Authority, 2014a). The incidence of poverty in agricultural households is three times that of non-agricultural ones, with farmers often facing "hungry seasons" when crops are not produced or climate shocks affect production (Reyes et al., 2012). By contrast, urbanized food systems, which provide reliable access to imported processed foods, have overdelivered, leading to obesity challenges in urban centers. Nearly one-quarter $(24 \%)$ of the national adult population is overweight and $5 \%$ is obese (International Food Policy Research Institute [IFPRI], 2015). Rapid population growth has concerned policy-makers for decades (Davidson, 2016; Zamora et al., 2013) and two broad focus areas have driven food and nutrition security policies. The first focus area has centered on improving farm productivity to create market surplus of staple commodities in an attempt to secure domestic self-sufficiency (Coxhead et al., 2001; Stone \& Glover, 2016). This focus area has prioritized the access, stability, and availability dimensions of food security, and has seen relative annual agricultural growth of $4 \%$. However, despite moderate income increases, the high cost of agrochemical inputs, climate shocks, and market access inequality has perpetuated poverty in rural areas. The incidence of poverty remains high in rural areas, with agrarian reform policies and market-led development failing to provide trickle-down benefits to farmers (Borras, 2007; Reyes et al., 2012).

The second focus area has been nutritional programs targeted at lower socioeconomic groups that prioritize food utilization (Zamora et al., 2013). An estimated 17\% of Philippine people do not meet their nutritional requirements and basic needs (Heckelman \& Wittman, 2015). Even when food is available, utilization might not be possible due to a lack of knowledge of healthy diets or access to clean water. Indigenous food production systems, including upland swidden systems, continue to provide basic food for families that have limited income opportunities and face multiple pressures from market-led development and agricultural policies (Cuevas et al., 2015; Dressler, 2005). Philippines food security is dependent on food imports to meet domestic demands for rice, a major cultural dietary staple (Davidson, 2016), making the country vulnerable to potential market shocks that see reductions in trade. When compared to global standards set by the World Health Organization's baseline indicators, the Philippines has severe levels of stunting (30.3\%) and underweight children (19.9\%), and medium severity in wasting (7.9\%) among children aged zero to five years (IFPRI, 2015). 
The food and nutrition security outcomes of the Philippine food system are not being achieved (Davidson, 2016). The state of human well-being is highly inequitable, with rural communities marginalized from development processes that have prevented their ability to achieve nutritious diets. The dominant support for staple commodities has created a system in which farmers depend on low incomes from cash crops, and landscapes have been modified to meet this international market demand. The ecological consequences and implications of this modification are discussed in the following section.

\section{State of agroecosystems}

Economic development policies in the Philippines have supported a series of industries that have had major impacts on land cover and natural resource use, such as mining, logging, and industrial agriculture (Bankoff, 2007; Davidson, 2016). In agriculture, land has been used to produce key commodities for domestic and international markets, posing threats to the country's unique biodiversity. The Philippines is home to rich ecosystems, with high rates of species endemism. Nearly half of the documented 1,100 terrestrial vertebrates are unique (Posa et al., 2008), and $60 \%$ of the 167 different mammal species and $65 \%$ of the over 10,000 plant species are endemic (Goldman, 2010). Heaney et al. (2016) found high levels of mammalian endemism in the main island of Luzon and discovered an additional 28 mammal species, nearly all endemic to the island. Marine ecosystems are equally diverse, with the Philippines being part of the Coral Triangle of the Pacific. The Coral Triangle has approximately 600 different species of reef-building corals, nurtures six of the world's seven marine turtle species, and more than 2,000 species of reef fish (Goldman, 2010). This diversity, which makes the Philippines one of the world's megabiodiverse countries, presents a major opportunity for developing food system activities that can support and sustain it.

Human activity has modified and affected Philippine ecosystems. Posa et al. (2008) identified habitat destruction from agricultural and forestry practices as major contributors of biodiversity loss in Philippine landscapes. These activities have stemmed from a range of socioeconomic challenges, including weak governance, corruption, lobbying, and increased human pressures. A combination of these factors has inhibited the progress of conservation action in the Philippines, despite a long history of civic engagement (Goldoftas, 2005). The lack of integration between conservation policies and other development priorities, such as rural development, has led to rapid landscape degradation (Maohong, 2012). Conservation activities need to compete with the continuation of national policies that promote agricultural expansion and intensification, inevitably perpetuating environmental degradation in the current production-oriented model (Coxhead et al., 2001). A series of national government bills have generated a policy discourse of ensuring national 
self-sufficiency in key commodities to secure food for the country, especially in rice (Davidson, 2016). This ongoing focus on land expansion for production practices continues to negatively affect the country's unique ecosystems (Wagner et al., 2015).

Coupled with land use changes, the national food system in the Philippines is facing major threats from climatic changes. Approximately 20 typhoons affect the country every year, with increasing intensity expected in the future. The El Niño effect resulted in prolonged droughts in the 1990s, causing a retraction in national GDP due to a dramatic drop in agricultural production (Lasco et al., 2009). As the intensity of droughts and typhoons increase with climate change, the vulnerability of rural communities is likely to increase. The volume of water available in watersheds will change, causing flooding in rainy seasons and greater deficits in dry seasons (Lasco et al., 2009). The impact of climate change on the food system will come in the form of reduced yields, livelihoods, and resource availability (Lasco et al., 2009, 2016). Low socioeconomic groups, largely comprised of food producers in coastal and inland areas, are the most vulnerable to changes in climatic conditions (Lasco et al., 2016).

Changing climates will likely reduce agricultural yields, increase the occurrence of heat stress in animals, and the incidence of pests and diseases (Lasco et al., 2016). Strategies for adapting to climate change in food systems remain largely targeted at protecting crops, rather than landscapes and people (Timmer, 2015). Consequently, food systems adaptation strategies have not been designed in a strategic and integrative way (Timmer, 2015). Given that $40 \%$ of the country's population remains in rural areas, mostly in agricultural landscapes (Philippine Statistic Authority, 2014b; UNDP, 2013), there is a critical need to build a knowledge base on how institutions can integrate climate concerns into food systems policies and research. Climatic changes indicate that future food systems will require adaptation strategies to reduce the impact on production and rural communities.

The Philippines' unique biodiversity and vulnerability to a changing climate create a state of ecosystems that influences food systems activities and interventions. Localized food systems throughout the country, notably indigenous systems and specific case studies in the literature, report a microcosm of biodiversity-friendly agriculture (Carpenter, 2003, 2010; Heckelman \& Wittman, 2015; Rambo \& Sajise, 1984; Wright, 2014). Although the majority of smallholder systems in the country work in intercropped systems, many policy and institutional incentives continue to be geared toward commodity production, marginalizing the importance of biodiversity and climate vulnerability contexts (Stone \& Glover, 2016). The next section examines how historical colonial legacies influenced the current state of institutions in the Philippines, creating a national food system focused on key export commodities. 


\section{State of food institutions}

The Philippines' agricultural system has a long tradition of producing for international markets, making the country a net food importer (Davidson, 2016). The dominant institutions established during the Philippines' occupation by Spain (1565-1899) and the US (1899-1941) determined, to a large extent, how land was used in the country. Since independence, a series of export-oriented programs and reductions in agricultural investments have stagnated the country's total food output (Davidson, 2016). Before Spanish colonization, forest cover was estimated to be $90 \%$; in 2015 , it was just $18 \%$, largely as a result of timber production and agricultural activities (Wagner et al., 2015). Prioritizing staple market commodities has affected the social and policy contexts in which the current food system operates in two main ways. First, the favoring of cash crops in agricultural policies has reduced the focus on diversifying livelihood opportunities (Davidson, 2016; UNDP, 2013). Second, the lack of farmer agency (in terms of political and economic power) has meant that farmers are often the passive recipients of knowledge and extension services (Olabisi, 2011).

When the Spanish colonized the Philippines in 1565, they quickly realized the country's economic potential and began exploiting its vast forest resources (Bankoff, 2007). In the 333 years of Spanish colonial rule, it has been estimated that $25 \%$ of total forested land in the Philippines was cleared. The expansion of Manila and other urban centers created a demand for timber products for buildings, leading to the establishment of a coherent, well-structured and specialized timber trade system by the late 1800s (Bankoff, 2007). There was also increasing demand for domestically produced food products, resulting in agricultural expansion throughout the country and further clearing of the forests. Forested land that could be converted to agriculture was sold to elite Spanish families (Bankoff, 2007), laying the groundwork for the inequitable land distribution system that still operates in the country today. There was legal and political support for the economic activities that underscored deforestation during Spanish colonization and this continued under US occupation.

The US occupied the country in 1899 . It took the US just 50 years to clear as much land as Spain had cleared in 333 years (Bankoff, 2007). The accessibility of the country's remaining forest cover, located within $120 \mathrm{~km}$ of the sea and with manageable topography, allowed for the expansion of timber as an export commodity to the US, Japan, China, and Europe. Land clearing was institutionalized; between 1900 and 1946, a range of public institutions were tasked with expanding the timber industry (Bankoff, 2007). Japan briefly occupied the Philippines between 1941 and 1945 and attempted to continue this trade in timber; however, external factors, such as the difficulty of procuring parts and securing good timber prices, prevented much timber production. When the Philippines became independent in 1946 , approximately $50 \%$ of the country's forested land remained. 
Under US occupation, the land ownership structures set up by Spain continued, as these facilitated the US's focus on commodity exports (Davidson, 2016; Borras, 2007). With the US as the primary importer, policy incentives and support for cash crops became the norm. Agricultural policy centered on supporting two major sectors: traditional and non-traditional. The traditional sector, which focused on corn, coconut, and sugarcane, continues to comprise $90 \%$ of total Philippine farmland (Borras et al., 2007; Davidson, 2016; Cororaton \& Corong, 2009). The non-traditional sector focused on high-value crops, such as bananas, mangoes, and pineapples (see Figure 3). Both agricultural sectors relied on smallholder farmers who worked land to which they had no legal title, and both sectors distributed the raw commodities to local and international private organizations and urban entrepreneurs (Borras et al., 2007).

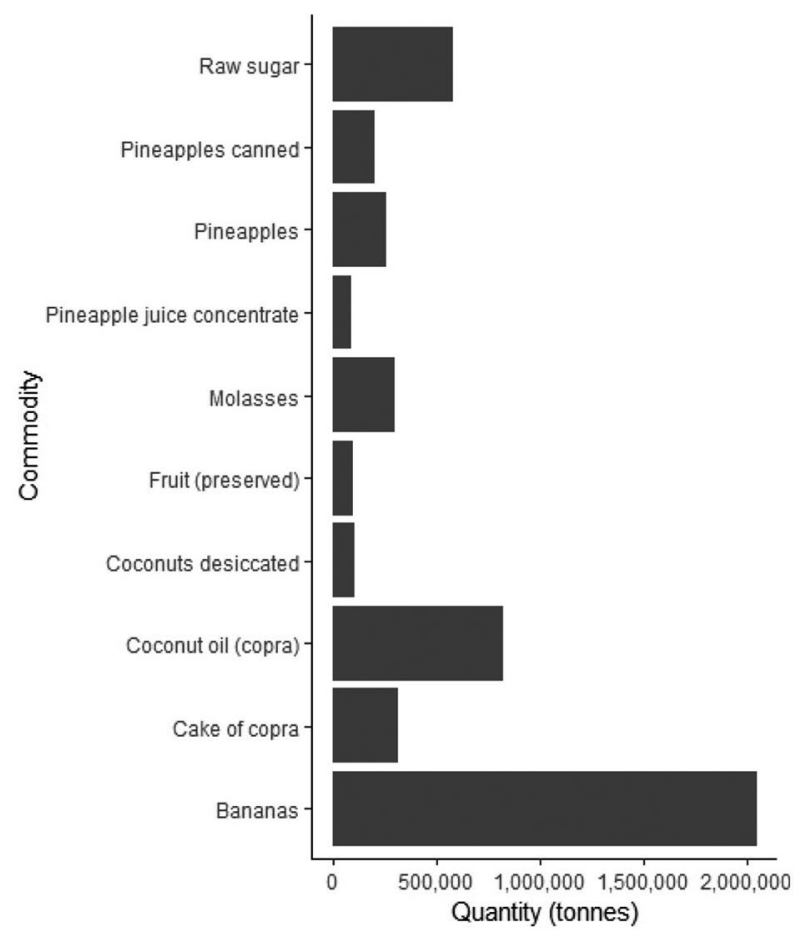

Figure 3. Top 10 export commodities

Source: Based on data from FAO (2011). 
The US Bell Trade Act of 1946, also known as the Philippine Trade Act, placed the US and elites in control of the majority of private businesses and cash crops grown in the Philippines for American markets (Maohong, 2012). US-owned sugar and coconut companies collaborated with elite Philippine landowners who exercised Western ideals of property rights. Political and institutional support for this type of landownership perpetuated the idea that informal smallholder and indigenous landownerships were illegal. The lack of recognition given to informal titles created opportunities for those who were legally and politically savvy to benefit from land laws, further pushing disadvantaged smallholders toward the margins. This lack of land rights, coupled with the ongoing need to produce food for export markets, created a system in which smallholders were laborers with minimal individual agency or power to influence policy processes (Borras, 2007).

A major factor that facilitated agricultural expansion in the Philippines after independence was institutional and political support for new technologies associated with the 'Green Revolution' (Davidson, 2016; Timmer, 2014, 2015). This led to the intensification of agriculture; a focus on specific commodities, including highyielding varieties; and an increased use of external inputs (Kastner \& Nonhebel, 2010; Kastner, 2009). This agricultural intensification prioritized key commodity production and failed to deliver positive nutritional outcomes for rural communities (UNDP, 2013). The establishment of the International Rice Research Institute in Los Baños is indicative of international efforts to provide agricultural technologies to the Philippines and the broader Southeast Asian region (Stone \& Glover, 2016) that effectively pushed indigenous and smallholder production knowledge systems to the margins and prevented them from diversifying their production practices (Coxhead, 2000).

As the population in rural areas increased, agricultural land ownership and reforms became a core concern for Philippine governments. Maohong (2012, p. 123) stated that since independence "virtually every president promulgated agrarian reform programs." Policies such as the Magna Carta of Small Farmers (Government of the Philippines, 1992) and Framework for the Right to Adequate Food (Government of the Philippines, 2014) represent political visions to achieve food security and social development. Yet, these have not been realized, largely because elites continue to hold greater power than smallholder farmers and continue to drive a highly industrial agricultural system (Borras, 2006, 2009; Franco \& Borras, 2007). The reality is that most smallholder producers lack formal land entitlements and risk being dislocated to make way for other land uses if they complain. The disjointed implementation of land reform and tolerance of corruption have amplified the negative impacts of land policies, thus perpetuating underdevelopment in rural areas (Lockie et al., 2012). 


\section{State of food discourses}

This complex history of commodity production and environmental change in the Philippines has led to two visions of improving food security, which, as Lockie (2005) has observed, are driven by different understandings of what food security means and how this translates into action. This has resulted in debate between the two main discourses that are seen as drivers of food and nutrition security outcomes (Jarosz, 2014; Leventon \& Laudan, 2017): food security and food sovereignty. Both discourses present different ways of framing food systems interventions (Chaifetz \& Jagger, 2014; Jarosz, 2014; Smith et al., 1992). Given the export policy context of the Philippines, the discourse of food security is concerned with providing access, availability, stability, and utilization of food to meet dietary needs. Framed as an economically oriented discourse, market food security ignores issues of social interactions, equity, gender, and environmental concerns (Jarosz, 2014). By contrast, the discourse of food sovereignty focuses on the rights of rural communities to frame and influence their immediate food systems. Both discourses operate in parallel; food security is generally aligned with large-scale interacting food systems and food sovereignty is often associated with localized systems (Leventon \& Laudan, 2017)

The historical context of the Philippine food system has been oriented toward high productivity and international markets (Lockie, 2005; Lockie et al., 2012). In terms of policy, Philippine food security is largely defined as existing when there is domestic self-sufficiency of key commodities, especially rice (Davidson, 2016; Timmer, 2014, 2015). This self-sufficiency poses geopolitical challenges for the region, which continues to pursue economic integration and neoliberal trade ideas (Desker et al., 2013). Moreover, the framing of food security as self-sufficiency in staple commodities limits the opportunity to reframe solutions that draw from diverse knowledge types on different production systems, such as those that exist among Philippine rural communities. For example, the use of participatory approaches (such as farmer field schools) can enable learning and observation of context-specific challenges that are often marginalized from macroeconomic narratives (Chandra et al., 2017; Daniel et al., 2014). Evidence from the Philippines shows the contribution that diverse knowledge systems can make to agricultural practices, especially at localized levels, which is where farmers and agricultural extension officers often interact (Carpenter, 2003, 2010; Wright, 2014).

The discourse of food sovereignty presents alternative ways of conceptualizing food activities and embracing diverse knowledge types. Food sovereignty is understood as the right of people and nations to control their own food systems, including markets, production models, food cultures, and environments (Wittman et al., 2010). The scale of food sovereignty is often local-communities can influence their production and consumption practices within specific legal and environmental settings (Cuevas et al., 2015). The discourse of food sovereignty sheds light on 
the economic and power structures that influence rural development (Chaifetz \& Jagger, 2014; Wittman et al., 2010). Food sovereignty activities have a strong presence in the Philippines; farmer movements have been advocating for justice, equity, and greater control over land for decades (Borras, 2006). There has also been considerable research on food sovereignty in the Philippines, including studies into the role of elite landownership and the disempowerment of farmers (Borras et al., 2007; Lockie, 2005; Lockie et al., 2012). Research focusing on smallholder agency and decision-making has highlighted the possibilities offered to diverse production systems and village institutions that empower farmers (Carpenter, 2003; Wright, 2014). Food sovereignty language is also present in national government documents. However, despite employing the language of farmer participation, there is little evidence of how (or whether) these documents are applied in rural areas. As Habito and Briones (2005) noted:

It is often remarked that the Philippine government has no shortage of good plans and programs to address various sectoral concerns, like those of the agricultural sector. It is, however, in the implementation of such plans and programs where the failures lie. (p. 12)

Like food security, food sovereignty is understood differently by different actors. This increases the level of tension and debate between food security and food sovereignty discourses (Chaifetz \& Jagger, 2014; Jarosz, 2014) and provides the opportunity for human ecology scholarship to analyze social drivers in food systems.

\section{Discussion}

The material presented above makes two contributions to analysis of the social drivers in food systems: first, it shows the complex history of land use in the Philippines at a macroeconomic level, and the implications of this for current environmental and social systems; second, it demonstrates how human ecology is a useful tool for capturing dominant discourses and the possible alternatives. In this discussion, I apply the material presented above to produce an overview of the current state of the human ecology of the Philippines' national food system. The feedback links are numbered and presented in the text with an "L" followed by the respective number.

\section{Maladaptive feedback processes in the Philippines}

Figure 4 synthesizes the literature analysis into the human ecology framework; each feedback process is explained in Table 3 . The analysis shows the tendency for public institutions to focus on the production of key commodities in the pursuit of economic growth (Coxhead et al., 2001; Davidson, 2016), presented here as the variable "extent of commodity intensification policies." This continues to be a dominant position in domestic agricultural policy in much of Southeast Asia, 
including the Philippines (Timmer, 2014, 2015; Habito \& Briones, 2005). This dominant focus has created a food system that is unable to achieve the outcome of food and nutrition security in which there is a stable supply and economic access to safe and nutrition food for the population (Coxhead, 2000; Davidson, 2016). This has led to inequitable health outcomes and low incomes in rural areas (Bankoff, 2007; UNDP, 2013; Zamora et al., 2013). L3 in Figure 4 shows how farmer incomes remain consistently low as policies maximize the production of key commodities, eroding any income diversification opportunities. Forest cover continues to decline as land use expands to produce cash commodities, as shown by L5 in Figure 4. The dominant discourse that prioritizes cash commodities as the main output drives the system's behavior (L1).

In Figure 4, all feedback processes feeding into the dominant state of discourses are positive (L2, L4, L6), amplifying the variable as the system behaves. For example, L2 presents a positive feedback that has been created by dominant historical land use activities, policies, and ownership laws in the Philippines (Borras, 2006; Cororaton \& Corong, 2009; Davidson, 2016; Desker et al., 2013). As policies for key commodities develop to balance international trade with domestic self-sufficiency (Desker et al., 2013), the dominant discourse of commodity production is perpetuated (L1). Figure 4 emphasizes the dominant systemic behavior driven by market-oriented food security policies (L1 and L2 feedback). This dominant discourse confirms research that contends that a market-oriented focus prevents alternative discourse and knowledge types from being included in food system activities (Clapp, 2015; Jarosz, 2014; Rivera-Ferre, 2012; Wittman et al., 2010). Human ecology analysis shows the challenges for intervening in a system that has failed to deliver human and environmental well-being. Sustained land degradation has been the product of the dominant discourse influencing behaviors and institutions, and a national discourse of food sovereignty focused on self-sufficiency will only perpetuate the system's behavior. The feedback processes create a maladaptive system that is unable to break from dominant patterns. This can have long-term implications for sustainability; for example, it is common for food decision-making institutions to be trapped in maladaptive cycles that prohibit new ways of framing problems and prevent solutions from emerging (Termeer et al., 2018), despite efforts to change such behaviors. 


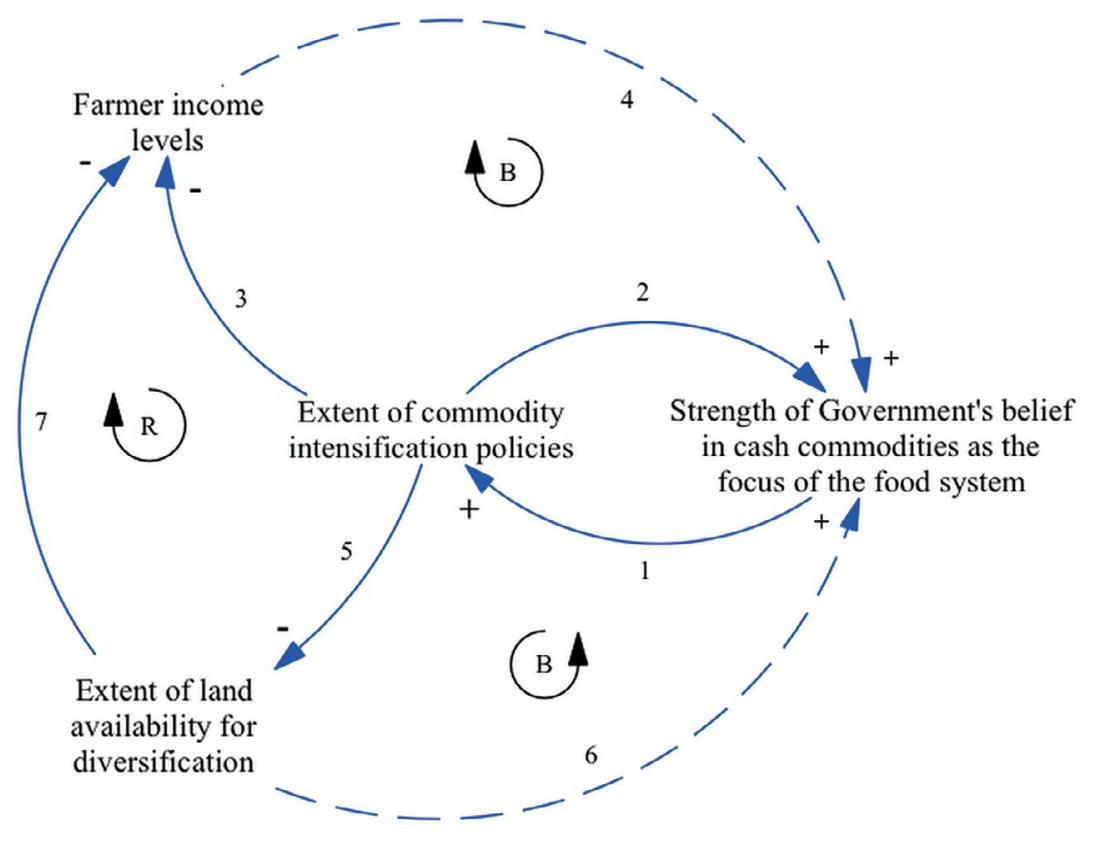

Figure 4. Human ecology of the Philippines' dominant food system

\section{Table 3. Explanation of links from Figure 4}

\begin{tabular}{|l|l|}
\hline Link Number & Process represented by the links \\
\hline 1 & $\begin{array}{l}\text { This link is positive. Historical influence has created a policy orientation to } \\
\text { increased productivity; this demonstrates the strength of the government's belief } \\
\text { in commodities. }\end{array}$ \\
\hline 2 & $\begin{array}{l}\text { This link is positive. Observations of declining agricultural productivity during the } \\
\text { last two decades have led to the strengthening of institutions charged with enacting } \\
\text { intensification policies. }\end{array}$ \\
\hline 3 & $\begin{array}{l}\text { This link is negative. As intensification efforts go up, farmers' incomes go down. } \\
\text { Rural incomes are vulnerable to market and environmental shocks. Poor nutrition } \\
\text { outcomes are representative of the negative state of health and well-being. }\end{array}$ \\
\hline 4 & $\begin{array}{l}\text { This link is positive but weak. If farmers' incomes went up, this would reinforce the } \\
\text { government policy. However, incomes are going down. This should drive policy in } \\
\text { the same direction. Falling farmer incomes ought to cause government to change } \\
\text { its stance, but it does not. This represents the weak sovereignty farmers have over } \\
\text { policy-making processes. }\end{array}$ \\
\hline 5 & $\begin{array}{l}\text { This link is negative. As the policy of commodity intensification goes up, the } \\
\text { behavioral response is the activity of land clearing, which results in the amount of } \\
\text { forested land area going down. The state of this variable is currently 18\% of land } \\
\text { cover and falling. }\end{array}$ \\
\hline 6 & $\begin{array}{l}\text { This link is positive, but weak. If forest cover were to increase under commodity } \\
\text { intensification programs, that ought to drive policy in the same direction (i.e., } \\
\text { strengthen it). In fact, forest cover is going down, so that ought to weaken the } \\
\text { policy. Forest loss can lead to erosion and biodiversity decline, which has been } \\
\text { documented to hinder long-term agricultural sustainability. }\end{array}$ \\
\hline
\end{tabular}




\begin{tabular}{|l|l|}
\hline Link Number & Process represented by the links \\
\hline 7 & $\begin{array}{l}\text { This link is negative. As farmers have few options to try to escape their commodity } \\
\text { trap other than to expand areas of production to increase total volumes, any effort } \\
\text { to increase forest cover would negatively affect their income. The consequence is } \\
\text { ongoing farmer efforts to clear forest cover as one of few strategies left to them } \\
\text { to increase their income. Eventually, farmers will be negatively impacted by this } \\
\text { strategy as ecosystem services are lost. Farmers may be aware of this, but the } \\
\text { short-term demands of their immediate perilous state of well-being do not give } \\
\text { them the luxury of taking this longer view into account. }\end{array}$ \\
\hline
\end{tabular}

An example of this maladaptation and the implications for food system outcomes is shown by the negative links between commodity production on household incomes (L3) and forest cover (L5). This is represented by L3; increased policy support for key commodities make farmers reliant on traders to supply agrochemical inputs and on commodity prices to secure incomes, which limits their capacity to come out of poverty (Davidson, 2016; Reyes et al., 2012). Increasing commodity prices will continue to act as signals for policies to transition from diverse commodity production systems to intense monocropped agricultural systems, often at the cost of local ecosystems (Cramb et al., 2009; Dressler et al., 2016). Philippine ecosystems provide biodiversity and services that continue to decline in abundance and heterogeneity as commodity production expands (L5) (Posa et al., 2008; Wagner et al., 2015). Continued reduction in agrobiodiversity presents barriers for sustaining household food consumption diversity, which can have negative long-term nutritional and environmental effects (Frei \& Becker, 2004; Zamora et al., 2013). The economic benefits likely to be generated from expanding cash commodity trades are unlikely to filter down to smallholder farmers as their landscapes continue to degrade, as shown in L7 (Borras, 2006; Borras, 2007). The experience of land conversion in the Philippines is similar to other Southeast Asian rural economies, in which cash commodities have degraded local knowledge and agrobiodiversity (Carpenter, 2003; Cramb et al., 2009; Dressler et al., 2016; Stone \& Glover, 2016). The dominant system is "trapped" in maladaptive behavior. However, the "weakness" of some feedback processes suggest possible points of intervention; these are documented across different small-scale food systems in the Philippines.

There are possible intervention points in the current maladaptive system presented in Figure 4, highlighted by the "weak" feedbacks in L4 and L6. Weak feedback processes can be used as leverage points to influence the behavior of a system toward more sustainable human and ecological outcomes. Such leverage points exist in L4, which, as it stands, sees small links between the ability of farmers to influence policy and the dominant market-oriented discourse. The second, L6, shows the current system in which policies addressing the link between commodity production and forest loss have been delayed. Both of these feedback processes are in transition, with multiple activities from localized food systems, research approaches, and new policy developments pointing to ways of reframing the dominant market discourse. 
An example of a leverage point comes from documented experiences in specific landscapes where alternative food production practices have challenged the dominant discourse. For example, there are extensive context-specific case studies that adapt practices to improve human and environmental systems through agroforestry, intercropping, organic practices, and participatory farmer learning activities (Carpenter, 2003, 2010; Frei \& Becker, 2004; Salazar, 2013; Sahakian et al., 2017; Rambo \& Sajise, 1984; Wright, 2014). Lessons from alternative practices demonstrate the critical role that formal farmer governance systems, such as cooperatives and organizations, play in creating opportunities for influencing current policy systems (L4) (Carpenter, 2003, 2010; Wright, 2014). Policy support for alternative practices is also emerging as a response to environmental degradation (L6). For example, there is rapid growth in organic practices as well as national policy requirements to have $5 \%$ of land cultivated under organic production (Sahakian et al., 2017; Salazar, 2013). Although organic production faces similar risks of monoculture and input dependency as industrial systems, there is growing recognition of the need to address environmental impacts in Philippine agriculture in light of growing population pressures, environmental change, and regional trade agreements (Depositario \& Saguiguit, 2014; Desker et al., 2013; Sahakian et al., 2017; Salazar, 2013). Equity issues, such as including marginalized farmer voices in governance processes (L4), are also growing in recognition through focusing on the sovereign right to food among the Philippine population (Government of the Philippines, 2014). Human ecology analysis provides insights into feedbacks in which alternative perspectives and approaches could shift current maladaptive behaviors. The application of the framework has provided a systems-based foundation to explore the role of dominant discourses in specific contexts. This foundation provides a template for expanding human ecology studies, thereby contributing to the growing use of social science approaches in food systems.

\section{Human ecology and food systems}

This analysis shows that human ecology is a useful tool for advancing studies into the social drivers influencing food system behavior. Given the complexity of food systems, it is important to understand how specific case studies are linked with regional governance and environmental changes (Ingram et al., 2010). The human ecological analysis conducted here shows how focusing on a country informs possible policy and research interventions based on the underlying food discourses. Human ecology and food systems are conceptually compatible, as they share underlying dynamic system principles that inform mixed methods and facilitate multistakeholder knowledge brokering activities. This makes human ecology a useful framework for studying how different food system actors understand food and nutrition security challenges, and for identifying possible intervention points to change the system's behavior. 
Human ecology offers a way of capturing how the issues across four core sustainability variables are connected through feedbacks. The framework highlights a specific problem as a symptom of the feedback processes in the system, and provides opportunities to intervene where weak feedbacks exist. The application to the Philippines shows how the maladaptive nature of the system has evolved through time, and provides a snapshot of possible intervention points. The application of the framework to the Philippines-and, in fact, any other national case study-offers insights into broader discussions into the complexity of governing food systems across different scales (Candel, 2014; Leventon \& Laudan, 2017). The systems foundation of human ecology, as presented here, is shared with both the food systems framework and emerging tools for analyzing the social and political aspects of food governance (Leventon \& Laudan, 2017; Termeer et al., 2018). Scholars' contributions toward food governance research (Candel, 2014; Hospes \& Brons, 2016; Termeer et al., 2018) present opportunities for human ecologists to use systems-based analysis to identify the influence of dominant discourses in different food systems.

In food systems research, there is increasing recognition of the value of conducting activities that are designed with locally relevant stakeholders to capture the different discourses and proposed solutions in a food system (Marin et al., 2016; RiveraFerre, 2012). Transdisciplinary research agendas based on systems approaches are growing; these require collaborative efforts and expertise that link up the multiple stakeholders concerned with particular problems. The overwhelming complexity of the social drivers of food systems can be managed by using human ecology to both guide stakeholders to explain how they perceive food insecurity challenges and build shared understandings of challenges across disciplines and sectors (Davila \& Dyball, 2018). This can guide the identification of competing ways of framing food challenges and contribute toward documenting novel transdisciplinary research approaches in food systems (Marin et al., 2016). Given the tensions that exist between localized food sovereignty discourses and the institutionalized market food security approaches that dominate food governance across different scales, such an approach is crucial (Candel, 2014; Leventon \& Laudan, 2017).

In future systems-based food policies, human ecological analysis can help practitioners to critically reflect on how institutional and governance responses have contributed, or not, to human and environmental well-being in food systems. Feedback guided analysis across different variables can help to identify situations in which policies have led to unintended outcomes, and leverage from possible weak feedbacks to experiment with changes. This will require novel governance arrangements that allow institutions to learn and intervene. Food will play a major role in delivering global sustainable development goals (Rockström et al., 2016), indicating the need to develop novel ways of investing, managing, and governing food to balance human and environmental well-being. 


\section{Conclusion}

This paper has demonstrated how human ecology helps to identify the dominant discourses that influence the social drivers in a food system. Human ecology in the Philippines has a strong history of exploring the role of humans in agricultural landscapes, and has recently re-emerged as a systems-based approach for contributing to regional visions of transdisciplinary research (Rambo, 1983; Rambo $\&$ Sajise, 1984; SEARCA, 2014). This makes the analysis presented here timely, as it contributes to the growing use of systems-based approaches to capture the underlying discourses that influence human behavior and their impact on sustainability. The complexity of food systems requires tools that share the same foundations and systems principles, but are able to capture how different social systems interact with their food environments. Ongoing applications and testing of human ecological analysis in different contexts will enable comprehensive food systems programs to emerge across different scales, linking and training future leaders in food systems management.

In the Philippines, food security-framed as self-sufficiency in terms of key commodities and achieved by maintaining exports- has presented limitations for diversifying and expanding smallholder and indigenous production systems. Smallholder farmers have failed to benefit from the economic gains made in the agricultural sector, with degraded landscapes, complex land entitlements, and the high cost of commodity production reducing opportunities for poverty reduction. Documented alternative production systems exist; these are driven by farmer organizations and cooperatives that seek to change the way that maladaptive policies influence localized food systems, offering possible pathways for improving environmental and human well-being.

The framework used here is limited, as it does not focus on power dynamics and their influence in food systems behavior. Further exploration of these unequal distributions of power and understandings of different ways to improve food security is critical. The framework implemented in this paper offers a step toward capturing the discourses that influence the state of a system. Future applications of human ecology need to be more cognizant of how the discourses are understood and applied by different actors in food systems, and the potential implications of this on power relations in specific food systems. Human ecology, as presented here, provides a systems-based analytical tool for identify the competing discourses in a specific food systems and their influence on the system's behavior. Ongoing use of the food systems framework will benefit from detailed studies of human and ecological change in the context of interacting discourses, ultimately bridging disciplines and providing policy insights to address food insecurity and work toward sustainable food systems. 


\section{Acknowledgments}

This study was supported by an Australian Government Research Training Program Scholarship. Thank you to various members of the Southeast Asian Regional Centre for Graduate Study and Research in Agriculture for insightful discussions. Thank you Lorrae van Kerkhoff, Tira Foran, and David Dumaresq for discussions and reviews of early versions of the manuscript.

\section{References}

Bankoff, G. (2007). One island too many: Reappraising the extent of deforestation in the Philippines prior to 1946. Journal of Historical Geography, 33(2), 314-334. doi.org/10.1016/j.jhg.2006.06.021

Borras, S. M. (2006). Redistributive land reform in "public" (forest) lands? Lessons from the Philippines and their implications for land reform theory and practice. Progress in Development Studies, 6(2), 123-145. doi.org/10.1191/1464993406ps132oa

Borras, S. M. (2007). "Free market," export-led development strategy and its impact on rural livelihoods, poverty and inequality: The Philippine experience seen from a Southeast Asian perspective. Review of International Political Economy, 14(1), 143-175. doi.org/ $10.1080 / 09692290601081426$

Borras, S. M. (2009). Agrarian change and peasant studies: changes, continuities and challenges - an introduction. The Journal of Peasant Studies, 36(1), 5-31. doi.org/ $10.1080 / 03066150902820297$

Borras, S. M., Carranza, D., \& Franco, J. C. (2007). Anti-poverty or anti-poor? The World Bank's market-led agrarian reform experiment in the Philippines. Third World Quarterly, 28(8), 1557-1576. doi.org/10.1080/01436590701637409

Candel, J. (2014). Food security governance: A systematic literature review. Food Security, 6(4), 585-601. doi.org/10.1007/s12571-014-0364-2

Carpenter, D. (2003). An investigation into the transition from technological to ecological rice farming among resource poor farmers from the Philippine island of Bohol. Agriculture and Human Values, 20(2), 165-176. doi.org/10.1023/A:1024013509602

Carpenter, D. (2010). Complementarity in the conservation of traditional and modern rice genetic resources on the Philippine island of Bohol. In S. Lockie \& D. Carpenter (Eds.), Agriculture, biodiversity and markets: Livelihoods and agroecology in comparative perspective (pp. 99-116). London, England: Earthscan.

Chaifetz, A., \& Jagger, P. (2014). 40 years of dialogue on food sovereignty: A review and a look ahead. Global Food Security, 3(2), 85-91. doi.org/10.1016/j.gfs.2014.04.002 
Chandra, A., Dargusch, P., McNamara, K. E., Caspe, A. M., \& Dalabajan, D. (2017). A study of climate-smart farming practices and climate-resiliency field schools in Mindanao, the Philippines. World Development, 98(Supplement C), 214-230. doi.org/ 10.1016/j.worlddev.2017.04.028

Clapp, J. (2015). Distant agricultural landscapes. Sustainability Science, 10(2), 305-316. doi.org/10.1007/s11625-014-0278-0

Clapp, J. (2017). The trade-ification of the food sustainability agenda. The Journal of Peasant Studies, 44(2), 335-353. doi.org/10.1080/03066150.2016.1250077

Cororaton, C. B., \& Corong, E. (2009). Philippine agriculture and food policies: Implications for poverty and income distribution. Washington, DC: International Food and Policy Research Institute.

Coxhead, I. (2000). Consequences of a food security strategy for economic welfare, income distribution and land degradation: The Philippine case. World Development, 28(1), 111-128. doi.org/10.1016/S0305-750X(99)00117-5

Coxhead, I., Shively, G., \& Shuai, X. (2001). Agricultural development policies and land expansion in a southern Philippine watershed. In A. Angelsen \& D. Kaimowitz (Eds.), Agricultural Technologies and Tropical Deforestation (pp. 347-365). New York, NY: CABI Pub. doi.org/10.1079/9780851994512.0347

Cramb, R. A., Colfer, C. J. P., Dressler, W., Laungaramsri, P., Le, Q. T., Mulyoutami, E., Peluso, N. L., \& Wadley, R. L. (2009). Swidden transformations and rural livelihoods in Southeast Asia, Human Ecology, 37(3), 323-346. doi.org/10.1007/s10745-009-9241-6

Cuevas, S. M. M., Fernandez, J. E. C., \& Olvida, I. (2015). Where peasants are kings: Food sovereignty in the Tagbanua traditional subsistence system. ASEAS-Austrian Journal of South-East Asian Studies, 81(1), 27-44.

Daniel, R., Borines, L., Soguilon, C., Montiel, C., Palermo, V., Guadalquiver, G. ... Guest, D. (2014). Development of disease management recommendations for the durian and jackfruit industries in the Philippines using farmer participatory research. Food Security, 6(3), 411-422. doi.org/10.1007/s12571-014-0352-6

Davidson, J. S. (2016). Why the Philippines Chooses to Import Rice. Critical Asian Studies, 48(1), 100-122. doi.org/10.1080/14672715.2015.1129184

Davila, F., \& Dyball, R. (2018). Food systems and human ecology: An overview. In A. Koenig (Ed.), Sustainability science: Key issues (pp. 183-210). London, England: Routledge.

Depositario, D. P., \& Saguiguit, G. (2014). SEARCA research thrusts and programmes through the years: The way toward food security. SEARCA.

Desker, B., Caballero-Anthony, M., \& Teng, P. (2013). Thought/issues paper on ASEAN food security: Towards a more comprehensive framework. ERIA Discussion Paper Series (ERIA-DP-2013-20). Singapura: Rajaratnam School of International Studies. 
Dressler, W. (2005). Disentangling Tagbanua lifeways, swidden and conservation on Palawan Island. Human Ecology Review, 12(1), 21-29.

Dressler, W. H., Wilson, D., Clendenning, J., Cramb, R., Keenan, R., Mahanty, S. ... Lasco, R. D. (2016). The impact of swidden decline on livelihoods and ecosystem services in Southeast Asia: A review of the evidence from 1990 to 2015. Ambio, 46(3), 1-20.

Dryzek, J. (1997). The politics of the earth: Environmental discourses. New York, NY: Oxford University Press.

Dyball, R., \& Newell, B. (2015). Understanding human ecology: A systems approach to sustainability. London, England: Routledge.

Ericksen, P. (2008). Conceptualizing food systems for global environmental change research. Global Environmental Change, 18(1), 234-245. doi.org/10.1016/j.gloenvcha. 2007.09.002

Fanzo, J. (2014). Strengthening the engagement of food and health systems to improve nutrition security: Synthesis and overview of approaches to address malnutrition. Global Food Security, 3(3), 183-192. doi.org/10.1016/j.gfs.2014.09.001

FAO (Food and Agriculture Organization). (2011). FAO Stat. Retrieved from:: faostat.fao. org/site/342/default.aspx

FAO (Food and Agriculture Organization). (2017). State of Food Insecurity 2017. Retrieved from: www.fao.org/3/a-I7695e.pdf

Franco, J. C., \& Borras, S. M. (2007). Struggles over land resources in the Philippines. Peace Review, 19(1), 67-75. doi.org/10.1080/10402650601181923

Frei, M., \& Becker, K. (2004). Agro-biodiversity in subsistence-oriented farming systems in a Philippine upland region: Nutritional considerations. Biodiversity and Conservation, 13(8), 1591-1610. doi.org/10.1023/B:BIOC.0000021330.81998.bb

Galt, R. E. (2013). Placing food systems in first world political ecology: A review and research agenda. Geography Compass, 7(9), 637-658. doi.org/10.1111/gec3.12070

Goldman, L. (2010). A biodiversity hotspot in the Philippines. Retrieved from: www.world wildlife.org/blogs/good-nature-travel/posts/a-biodiversity-hotspot-in-the-philippines

Goldoftas, B. (2005). The green tiger: The costs of ecological decline in the Philippines. Oxford, England: Oxford University Press.

Government of the Philippines. (1992). Magna Carta of Small Farmers. Retrieved from: www.acpc.gov.ph/wp-content/uploads/2015/11/RA7606.pdf

Government of the Philippines. (2014). An Act providing a framework for the right to adequate food. Senate Number 2137. Retrieved from: www.senate.gov.ph/lisdata/1877315901!.pdf 
Habito, C., \& Briones, R. (2005). Philippine agriculture over the years: Performance, policies and pitfalls. Paper presented at Policies to Strengthen Productivity in the Philippines, conference sponsored by the Asia-Europe Meeting (ASEM) Trust Fund, Makati City, Philippines.

Heaney, L. R., Balete, D. S., Duya, M. R. M., Duya, M. V., Jansa, S. A., Steppan, S. J., \& Rickart, E. A. (2016). Doubling diversity: A cautionary tale of previously unsuspected mammalian diversity on a tropical oceanic island. Frontiers of Biogeography, 8(2), 1-19.

Heckelman, A., \& Wittman, H. (2015). Food sovereignty: A framework for assessing agrarian responses to climate change in the Philippines. Austrian Journal of South East Asian Studies, 8(1), 87-94.

Hospes, O., \& Brons, A. (2016). Food system governance: A systematic literature review. In A. Kennedy \& J. Liljeblad, Food systems governance: Challenges for justice, equality and human rights (pp. 13-42). New York, NY: Routledge.

IFPRI (International Food Policy Research Institute). (2015). Global nutrition report: The Philippines. Retrieved from: ebrary.ifpri.org/utils/getfile/collection/p15738coll2/ id/130014/filename/130225.pdf

Ingram, J. (2011). A food systems approach to researching food security and its interactions with global environmental change. Food Security, 3(4), 417-431. doi.org/10.1007/ s12571-011-0149-9

Ingram, J. (2017). Perspective: Look beyond production. Nature, 544(7651), S17-S17. doi.org/10.1038/544S17a

Ingram, J., Ericksen, P., \& Liverman, D. (2010). Food security and global environmental change. London, England: Earthscan.

IPES Food (International Panel of Experts on Sustainable Food Systems. (2015). The new science of sustainable food systems: Overcoming barriers to food systems reform. Retrieved from: www.ipes-food.org/images/Reports/IPES_report01_1505_web_br_pages.pdf

Jarosz, L. (2014). Comparing food security and food sovereignty discourses. Dialogues in Human Geography, 4(2), 168-181. doi.org/10.1177/2043820614537161

Kastner, T. (2009). Trajectories in human domination of ecosystems: Human appropriation of net primary production in the Philippines during the 20th century. Ecological Economics, 69(2), 260-269. doi.org/10.1016/j.ecolecon.2009.08.019

Kastner, T., \& Nonhebel, S. (2010). Changes in land requirements for food in the Philippines: A historical analysis. Land Use Policy, 27(3), 853-863. doi.org/10.1016/ j.landusepol.2009.11.004

Lasco, R. D., Espaldon, M. L. O., \& Habito, C. M. D. (2016). Smallholder farmers' perceptions of climate change and the roles of trees and agroforestry in climate risk adaptation: Evidence from Bohol, Philippines. Agroforestry Systems, 90(3), 521-540. doi.org/10.1007/s10457-015-9874-y 
Lasco, R. D., Pulhin, F. B., Jaranilla-Sanchez, P. A., Delfino, R. J. P., Gerpacio, R., \& Garcia, K. (2009). Mainstreaming adaptation in developing countries: The case of the Philippines. Climate and Development, 1(2), 130-146. doi.org/10.3763/cdev.2009.0009

Leventon, J., \& Laudan, J. (2017). Local food sovereignty for global food security? Highlighting interplay challenges. Geoforum, 85, 23-26. doi.org/10.1016/j.geoforum.2017.07.002

Lockie, S. (2005). Interpreting the Australian-Philippines food trade in the context of debates on food security. In N. Fold \& B. Prittchard (Eds.), Cross-continental food chains. London, England: Taylor and Francis Group.

Lockie, S., Tennent, R., Benares, C., \& Carpenter, D. (2012). Is de-agrarianization inevitable? Subsistence, food security and market production in the uplands of Negros Occidental, the Philippines. Int. J. Sociol. Agric. Food, 19(2), 214-228.

Maohong, B. (2012). Deforestation in the Philippines, 1946-1995. Philippine Studies: Historical and Ethnographic Viewpoints, 60(1), 117-130. doi.org/10.1353/phs.2012.0011

Marin, A., Ely, A., \& van Zwanenberg, P. (2016). Co-design with aligned and non-aligned knowledge partners: Implications for research and coproduction of sustainable food systems. Current Opinion in Environmental Sustainability, 20, 93-98. doi.org/10.1016/ j.cosust.2016.09.003

McIntyre, B. D., Herren, H. R., Wakhungu, J., \& Watson, R. T. (2009). International assessment of agricultural knowledge, science and technology for development (IAASTD): Global report. Washington, DC: World Bank.

McMichael, P. (Ed.). (1994). The global restructuring of agro-food systems. New York, NY: Cornell University Press.

Olabisi, L. S. (2011). Uncovering the root causes of soil erosion in the Philippines. Society \& Natural Resources, 25(1), 37-51. doi.org/10.1080/08941920.2011.563435

Philippine Statistic Authority. (2014a). Poverty statistics. Retrieved from: psa.gov.ph/psapress-release-tags/poverty-statistics

Philippine Statistic Authority. (2014b). Urban-rural classification. Retrieved from: psa.gov. $\mathrm{ph} /$ tags/urban-rural-classification

Posa, M. R. C., Diesmos, A. C., Sodhi, N. S., \& Brooks, T. M. (2008). Hope for threatened tropical biodiversity: Lessons from the Philippines. Bioscience, 58(3), 231-240. doi.org/ 10.1641/B580309

Rambo, T. (1983). Conceptual approaches to human ecology. Honolulu, HI: East-West Environment and Policy Institute.

Rambo, T., \& Sajise, P. (Eds.). (1984). An introduction to human ecology research on agricultural systems in Southeast Asia. Laguna, Philippines: University of the Philippines and EastWest Environment and Policy Institute, University of the Philippines Los Baños. 
Reyes, C. M., Tabuga, A. D., Asis, R. D., \& Datu, M. B. G. (2012). Poverty and agriculture in the Philippines: Trends in income poverty and distribution. Makati, Philippines: Philippine Institute for Development Studies.

Rivera-Ferre, M. (2012). Framing of agri-food research affects the analysis of food security: The critical role of the social sciences. International Journal of Sociology of Agriculture and Food, 19(2), 162-175.

Rockström, J., Williams, J., Daily, G., Noble, A., Matthews, N., Gordon, L. ... Smith, J. (2016). Sustainable intensification of agriculture for human prosperity and global sustainability. Ambio, 1-14.

Sahakian, M., Leuzinger, T., \& Saloma, C. (2017). Uncovering changing prescriptions and practices around organic agriculture in Metro Manila, the Philippines. Agroecology and Sustainable Food Systems, 41(5), 505-525. doi.org/10.1080/21683565.2017.1284173

Salazar, R. C. (2013). Going organic in the Philippines: Social and institutional features. Agroecology and Sustainable Food Systems, 38(2), 199-229. doi.org/10.1080/21683565. 2013.833155

SEARCA (Southeast Asian Regional Center for Graduate Study and Research in Agriculture). (2014). Pathways toward inclusive, sustainable and rural development in Southeast Asia: Tenth five-year plan of SEAMEO SEARCA 2014-2019,. Retrieved from: searca.org/ phocadownload/brochures/pathways-to-isard.pdf

Smith, M., Pointing, K., \& Maxwell, S. (1992). Household food security, concepts and definitions: An annotated bibliography (Development Bibliography No 8). Sussex, England: Institute of Development Studies, Brighton, University of Sussex.

Sobal, J., Kettel Khan, L., \& Bisogni, C. (1998). A conceptual model of the food and nutrition system. Social Science \& Medicine, 47(7), 853-863. doi.org/10.1016/S02779536(98)00104-X

Stone, G. D., \& Glover, D. (2016). Disembedding grain: Golden rice, the green revolution, and heirloom seeds in the Philippines. Agriculture and Human Values, 34(1), 87-102.

Termeer, C. J. A. M., Drimie, S., Ingram, J., Pereira, L., \& Whittingham, M. J. (2018). A diagnostic framework for food system governance arrangements: The case of South Africa. NJAS_Wageningen Journal of Life Sciences. 84(Supplement C), 85-93. doi.org/ 10.1016/j.njas.2017.08.001

Timmer, P. (2014). Food security in Asia and the Pacific: The rapidly changing role of rice. Asia o the Pacific Policy Studies, 1(1), 73-90. doi.org/10.1002/app5.6

Timmer, P. (2015). The dynamics of agricultural development and food security in Southeast Asia: historical continuity and rapid change. In I. Coxhead (Ed.), Routledge handbook of Southeast Asian economics (pp. 89-113). New York, NY: Routledge.

UNDP (United Nations Development Programme). (2013). 2012/2013 Philippine human development report. Nairobi, Kenya: United Nations Development Programme. 
Vermeulen, S. J., Aggarwal, P. K., Ainslie, A., Angelone, C., Campbell, B. M., Challinor, A. J. ... Wollenberg, E. (2012). Options for support to agriculture and food security under climate change. Environmental Science \& Policy, 15(1), 136-144. doi.org/10.1016/ j.envsci.2011.09.003

Wagner, A., Yap, D. L. T., \& Yap, H. T. (2015). Drivers and consequences of land use patterns in a developing country rural community. Agriculture, Ecosystems \& Environment, 214. 78-85. doi.org/10.1016/j.agee.2015.08.016

Wittman, H., Desmarais, A. A., \& Wiebe, N. (2010). The origins and potential of food sovereignty. In H. Wittman, D. Annette Aurélie, \& N. Wiebe (Eds.), Food sovereignty: Reconnecting food, nature and community (pp. 1-12). Winnipeg, Canada: Fernwood.

Wright, S. (2014). Food sovereignty in practice: A study of farmer-led sustainable agriculture in the Philippines. In P. Andree, J. Ayres, M. Bosia, \& M. J. Massicotte (Eds.), Globalization and food sovereignty: Global and local change in the new politics of food (pp. 199-227). Toronto, Canada: University of Toronto Press.

Zamora, O., de Guzman, L., Saguiguit, S., Talavera, M. T., \& Gordoncillo, N. (2013). Leveraging agriculture to improve nutrition in the Philippines. Food Security, 5(6), 873-886. doi.org/10.1007/s12571-013-0306-4 
This text is taken from Human Ecology Review, Volume 24, Number 1, 2018, published 2018 by ANU Press, The Australian National University, Canberra, Australia.

doi.org/10.22459/HER.24.01.2018.02 